\title{
DAMPAK PENGEMBANGAN PROGRAM EKOWISATA BERBASIS SATWA ENDEMIK DI TANGKOKO BITUNG
}

\author{
Fergina Baware, H. J. Kiroh*, R. H. Wungow, M. Kawatu \\ Fakultas Peternakan Universitas Sam Ratulangi Manado, 95115
}

\begin{abstract}
ABSTRAK
Cagar alam Tangkoko dan Dua Saudara merupakan cagar alam yang terletak di kota Bitung Sulawesi Utara dengan luas 8.745 Ha. Di Tangkoko terdapat keragaman hayati yaitu berbagai jenis flora dan fauna yang dilindungi. Di antaranya juga terdapat beberapa satwa endemik seperti monyet hitam Sulawesi (Macaca nigra), tarsius (Tarsius spectrum), Kuskus beruang Sulawesi (Ailurops ursinus), burung rangkong (Rhyticeros cassidix). Di sinilah wisatawan dapat menikmati keindahan atau melihat secara langsung kekayaan alam yang terdapat di hutan lindung Tangkoko. Dimana hutan ini memiliki potensi sebagai lokasi Ekowisata. Industri pariwisata mempunyai peranan penting dalam upaya pembangunan dan pengembangan suatu daerah. Bahkan pada beberapa daerah menunjukan bahwa industri pariwisata mampu mengangkat daerah tersebut dari keterbelakangan dan menjadikan sebagai sumber pendapatan utama. Berdasarkan hal tersebut maka dilakukan penelitian Dampak pengembangan ekowisata berbasis satwa endemik di Cagar Alam Tangkoko Bitung pada tanggal 12 November sampai dengan 12 Januari 2017. Tujuan penelitian ini adalah untuk mengetahui dampak pengembangan ekowisata terhadap satwa endemik (Monyet Hitam Sulawesi dan Tarsius). Materi yang digunakan dalam adalah fauna endemik (Monyet Hitam Sulawesi dan Tarsius), dengan
\end{abstract}

*Korespondensi (corresponding author) Email: wakilrektor3_hk@yahoo.com

menggunakan metode survey. Data diperoleh melalui wawancara langsung dengan masyarakat di sekitar area cagar alam, melalui pemerintah terkait di Kota Bitung. Variabel yang diamati adalah 1) vegetasi, 2) kondisi satwa yang ada dilokasi, 3) pendapatan masyaraat, 4) pendapatan daerah.

Dari data dan hasil pembahasan dapat disimpulkan bahwa program Ekowisata sangat baik untuk dikembangkan karena dapat memberi dampak positif terhadap usaha konservasi, meningkatkan pendapatan masyarakat serta pendapatan daerah.

Kata Kunci: Ekowisata, Fauna Endemik, Tangkoko

ABSTRACT
THE IMPACT OF ENDEMIC
PROGRAM
ECOTOURISM
DEVELOPMENT ONED
TANGKOKO NATURE RESERVE OF
BITUNG. Tangkoko National Reserve is
one of the nature reserves located in Bitung
regency of North Sulawesi. The reserve
covers an area of 8,745 hectares. There is
abundant biodiversity such as various types
of protected flora and fauna can be found in
the reserve. Among them there are endemic
wildlifes such as Sulawesi Macaque
(Macaca nigra), Tarsiers (Tarsius
spectrum), the Sulawesi bear cuscus
(Ailurops ursinus), and Hornbill
(Rhyticeros cassidix). Here is where the
tourists can enjoy the beauty of the reserve
or seen firsthand the wealthy of nature in
such a protected forest, where the forest has


potential as anecotourism spot. Tourism industry has an important role in the development efforts and the development of the region where the tourism spot located.Even in some areas show that tourism industry is able to develop the region as well as create a main income source. The present study was conducted to elaborate the impacts of endemic ecotourism program development basedon the development of Tangkoko nature reserve of Bitung. The study was conducted from November 2016 to January 2017. The ellaboration of the study was focused on the impact of ecotourism developmentonthe existing endemic Sulawesi Black Monkeys and Tarsiers. Survey method was employed to collect and analyze various data and information on endemic fauna of Sulawesi Black Monkeys and Tarsiers. The primary data was obtained through direct interviews with various communities around nature reserve area, and secondary data was obtained from related government sources in Bitung regency.Variables observed were:1) vegetation, 2) the existing wildlife conditions, 3) community income, and 4) the income of the region of Bitung regency.Based on results and discussion, it can be concluded that ecotourism is the best program to be implemented as it could give positive impact towards conservation efforts,increase community's income, and regional income.

Keywords: Tangkoko reserve, Ecotourism, Endemic Fauna.

\section{PENDAHULUAN}

Industri pariwisata mempunyai peranan penting dalam upaya pembangunan dan pengembangan suatu daerah. Bahkan pada beberapa daerah menunjukan bahwa industri pariwisata mampu mengangkat daerah tersebut dari keterbelakangan dan menjadikan sebagai sumber pendapatan utama. Cagar alam Gunung Tangkoko dan Dua Saudara merupakan cagar alam yang terletak di kota Bitung Sulawesi Utara dengan Luas 8.745 hektar. Di Tangkoko terdapat keragaman hayati yaitu berbagai jenis flora dan fauna yang dilindungi. Di antaranya juga terdapat beberapa satwa endemik seperti Monyet hitam Sulawesi (Macaca nigra), Tarsius (Tarsius spectrum), Kuskus beruang Sulawesi (Ailurops ursinus), Burung rangkong (Rhyticeros cassidix). Di sinilah, wisatawan dapat menikmati keindahan atau melihat secara langsung kekayaan alam yang terdapat di hutan lindung Tangkoko. Di kawasan hutan juga bisa dilakukan kegiatan-kegiatan konservasi dan kegiatan lainnya seperti kegiatan petualang (adventure) menelusuri belantara hutan dan kegiatan untuk menikmati keindahan alam flora dan fauna sekaligus menjadi bagian dari program ekowisata. Usaha ini tentunya akan memberikan dampak positif bagi pemerintah daerah dan masyarakat, karena dapat meningkatkan pendapat asli daerah (PAD) dan sekaligus meningkatkan ekonomi masyarakat yang bermukim di wilayah pengembangan ekowisata. Bila ekowisata seperti ini dikembangkan maka diharapkan kelestarian flora dan fauna endemik akan semakin terlindung karena dapat ditangani secara terkontrol lewat pendekatan masyarakat lokal. Selain 
dampak positif, mungkin juga terdapat dampak negatif akibat kunjungan wisata terhadap satwa terutama terhadap kelestarian satwa.

\section{MATERI DAN METODE PENELITIAN}

Penelitian ini telah dilaksanakan pada tanggal 12 November 2016 sampai dengan tanggal 12 januari 2017 bertempat di Taman Wisata alam Batuputih Kawasan Tangkoko di kota Bitung Sulawesi Utara. Objek dalam penelitian ini adalah fauna endemik, masyarakat (responden 75 orang) yaitu $15 \%$ dari kepala keluarga di Tangkoko/ zona kunjungan desa Batuputih dan instansi pemerintah di Kota Bitung. Peralatan yang digunakan dalam penelitian ini adalah peralatan dokmentasi (Kamera Digital), ATM (Alat Tulis Menulis), Komputer untuk mengolah data, dan kuesioner dalam bentuk daftar pertanyaan yang berkaitan dengan dampak pengembangan ekowisata terhadap satwa endemik.

Metode yang digunakan dalam penelitian ini adalah metode survey lapangan, serta melakukan wawancara dengan masyarakat, wisatawan dan petugas pemandu yang ada disekitar Taman Wisata Alam Batuputih Kawasan Hutan Konservasi Tangkoko. Variabel yang diamati adalah: 1). Vegetasi, 2). Kondisi satwa yang di lokasi, yang terdiri dari: fauna yang terlihat oleh masyarakat, pengetahuan masyarakat terhadap gangguan fauna, respon masyarakat terhadap pengembangan ekowisata dan peran instansi pemerintah terhadap konservasi sumber daya alam, 3). Pendapatan masyarakat, 4). Pendapatan Daerah/PAD, yang diambil dari: Dinas Pariwisata dan DIPENDA.

Metode pengumpulan data berlangsung dalam 3 tahap, yaitu:

1. Orientasi Lapangan

Orientasi lapangan dilakukan dengan tujuan untuk mempermudah dalam penentuan lokasi serta mengamati kondisi satwa endemik yang masih berkembang di kawasan Cagar Alam Tangkoko, dan dampaknya terhadap masyarakat sekitar. Orientasi lapangan selama 7 hari untuk megetahui situasi serta kondisi lapangan baik satwa endemik yang ada, maupun pemandu wisata atau petugas dan masyarakat disekitar lokasi pengembangan ekowisata, serta wisatawann yang dijumpai selama penelitian

\section{Pengumpulan Data}

Data dikumpulakan dengan cara mendatangi langsung responden dan mewancarai dengan berbagai pertanyaan yang telah di persiapkan sebelumnya dalam bentuk kuesioner.

\section{Analisis Data}


Data yang diperoleh ditabulasi dan dianalisis dengan menghitung presentasi dari tiap-tiap varieabel yang terkait dengan pengembangan ekowisata berbasis fauna endemik di Cagar Alam Tangkoko.

\section{HASIL DAN PEMBAHASAN}

Cagar Alam Tangkoko secara geografis terletak di ujung utara Pulau Sulawesi bagian Utara, Kecamatan Bitung Utara, Kota Bitung. Luas Cagar Alam Tangkoko dan Dua Saudara adalah 8.745 hektar (Hakim, 2010). Secara umum Cagar Alam Tangkoko mempunyai topografi dari landai sampai bergunung, jenis tanah digolongkan sebagai regosol.

\section{Tingkat Pendidikan Masyarakat Disekitar Taman Wisata Alam Tangkoko}

Pendidikan masyarakat merupakan salah satu faktor yang ikut mempengaruhi tingkat pemahaman terhadap pengembangan ekowisata berbasis satwa endemik yang ada di taman wisata alam Tangkoko. Hasil yang diperoleh dari masyarakat (responden) yang berada di sekitar taman wisata alam Tangkoko Batuangus Bitung SULUT menunjukan bahwa pendidikan masyarakat di sekitar taman wisata alam Tangkoko sangat bervariasi untuk lebih jelas dapat dilihat pada Diagram 1 di bawah ini. Terlihat dari data diatas bahwa jumlah masyarakat (responden) yang mencapai sekolah dasar yaitu 20\%, sedangkan untuk tingkat pendidikan SMP mendekati sekolah dasar Yaitu 16\%. Masyarakat yang melanjutkan pendidikan ke tingkat SMU tertinggi mencapai $50,7 \%$ dan untuk pendidikan tinggi sarjana di temukan terendah yaitu 13,3\%. Hasil di atas dihubungkan dengan hasil wawancara penelitian dengan kepala desa Batuputih Bawah, bahwa di desa

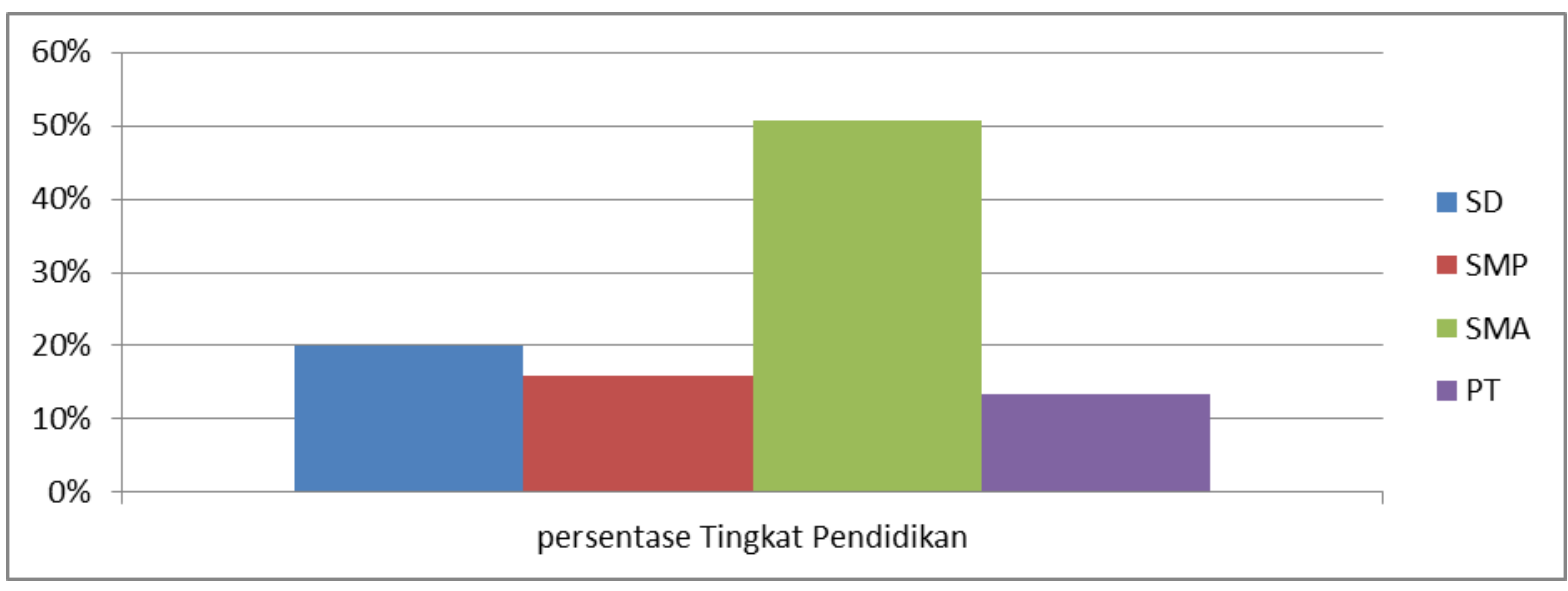

Diagram 1. Persentase Tingkat Pendidikan Masyarakat (Responden) Di Sekitar Taman Wisata Alam Tangkoko Batuangus Bitung. 
Batuputih Bawah terdapat dua sekolah dasar, satu tingkat pendidikan SMP dan satu tingkat pendidikan SMU/SMK. Sedangkan untuk tingkat pendidikan tinggi sarjana msyarakat harus ke kota untuk mendapatkannya.

Gambaran pendidikan masyarakat ini menunjukan bahwa semakin tinggi tingkat pendidikan seseorang, maka mereka akan lebih cepat dalam menerima suatu informasi baru, maka dengan sendirinya jika upaya perlindungan terhadap flora dan fauna terus dikembangkan maka mereka juga aktif ikut berperan dalam memberikan dampak kepada masyarakat yang berpendidikan rendah. Disamping itu pendidikan juga merupakan salah satu cara penunjang dalam pembangunan di berbagai sektor termasuk di dalamnya sektor industri pariwisata.

\section{Vegetasi.}

Tipe vegetasi di Cagar Alam Tangkoko dominan adalah hutan hujan dataran rendah dengan jenis pohon dominan adalah Dracontomelum dao, Palaquiumobovatum, Palaquium obtusifolium, Cananga odorata, Ficus variegata, Homalium celebicum, Tetrameles nudiflora, Planchonia valida, Gostampinus valetonii, jenis palem Livistona rotundifolia,
Amorphophallus campanulatus, Leea rubra, Leea. indica, dan rotan Calamus sp.

Hutan hujan pegunungan yang terdapat di kawasan ini didominasi oleh vegetasi Beringin (Ficus spp), Aras (Duabanga moluccana), Nantu (Palaquim obtusifolium), sedangkan pada hutan lumut dapat ditemui Bunga Edelweis (Anaphalis javanicum) dan Kantong Semar (Nephentes gynamphoru). Tipe vegetasi hutan pantai didominasi oleh Calophyllum soulattri dan Barringtonia asiaticahHutan sekunder didominasi oleh Casuarina equisetifolia dan juga terdapat padang alang-alang Imperata cylindrica (Tarmudji dan MacKinnon, 1980).

\section{Kondisi satwa yang ada di lokasi fauna yang terlihat oleh masyarakat di Taman Wisata Alam Tangkoko.}

Fauna endemik Taman Wisata Alam Tangkoko memiliki keunikan yang mempunyai potensi untuk dikembangkan. Kota Bitung sangat baik untuk dijadikan daerah ekowisata karena didukung dengan adanya fauna yang sangat khas seperti burung Rangkong, Hantu, Elang, Raja Udang, Monyet Hitam Sulawesi, Tarsius, Kuskus, Maleo, Babi Hutan dan lain-lain. Untuk mengetahui masyarakat yang tinggal di sekitar Taman Wisata Alam Tangkoko yang pernah melihat fauna khas tersebut dapat dilihat pada Diagram 2 . 


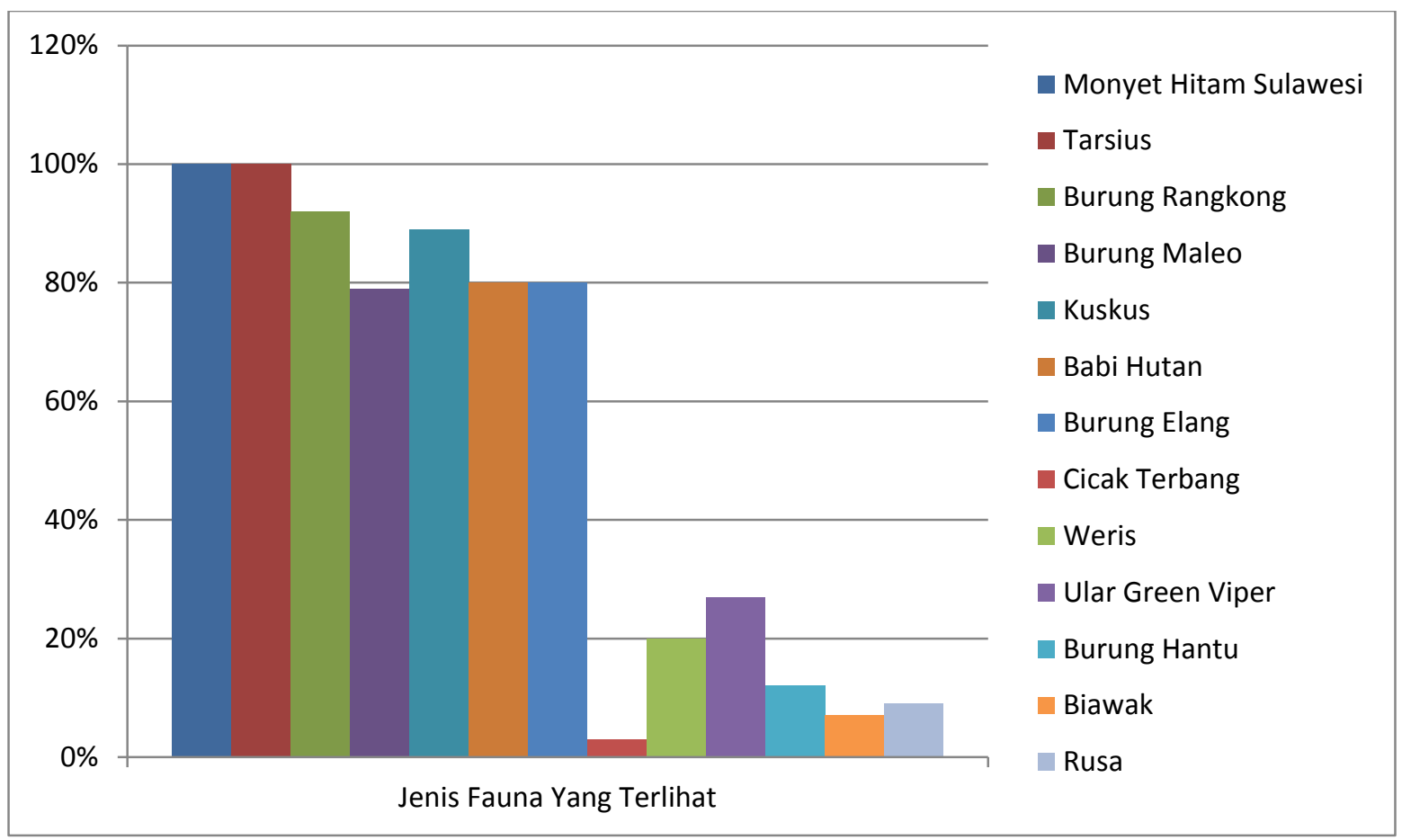

Diagram 2. Jenis Fauna yang terlihat Oleh Masyarakat (Responden) Di Taman Wisata Alam Tangkoko.

Dari hasil penelitian diatas menunjukan bahwa masyarakat (responden) yang bermukiman di sekitar Taman Wisata Alam Tangkoko rata-rata pernah malihat satwa (fauna) endemik, dimana hasil penelitian menunjukan bahwa besarnya persentase masyarakat yang pernah melihat satwa endemik yaitu ratarata $100 \%$, sedangkan persentase masyarakat yang ada di sekitar Taman Wisata Alam yang tidak pernah melihat satwa endemik adalah $(0 \%)$ dengan alasan karna masyarakat-masyarakat ini tempat tinggal sangat dekat dengan hutan dan selalu hidup berdampingan dengan hutan.

Berdasarkan data yang diperoleh dari penelitian ini menunjukan bahwa peluang untuk pengembangan fauna endemik untuk dijadikan ekowisata di Taman Wisata Alam Tangkoko sangat baik.

\section{Pengetahuan masyarakat tentang adanya gangguan terhadap fauna endemik di Taman Wisata Alam Tangkoko}

Sesuai Undang-Undang Konservasi hewan bahwa hewan-hewan langka endemik yang hampir punah harus dilindungi dimana masyarakat tidak diberi kesempatan untuk menangkap atau memeliharanya, dengan adanya undangundang di atas maka Monyet Hitam Sulawesi (macacanigra) salah satu hewan endemik yang ada di hutan Taman Wisata Alam Tangkoko yang harus dilindungi. 
Taman Wisata Alam Tangkoko banyak menyimpan kekayaan hayati flora dan fauna endemik yang tinggi dan memiliki nilai ekonomis bila terus dilindungi dan dikembangkan sebagai kegiatan wisata alam dengan tampilan hewan-hewan khas daerah. Hasil penelitian menunjukan bahwa masih ada sebagian kecil masyarakat di sekitar Taman Wisata Alam Tangkoko yang melakukan aktivitas di hutan dan untuk mengetahui lebih jauh beberapa besarnya persentase masyarakat yang mengetahui adanya kegiatan-kegiatan masyarakat seperti berkebun atau penangkapan satwa liar misalnya babi hutan, burung maleo, burung rangkong, monyet hitam sulawesi. Hasil penelitian ditemukan bahwa besarnya nilai persentase masyarakat yang mengetahui adanya kegiatan masyarakat di Taman Wisata Alam Tangkoko ditemukan 45,3\%. Sedangkan masyarakat yang tidak mengetahui adanya aktivitas di Taman Wisata Alam Tangkokomencapai nilai persentase $54,7 \%$. Aktivitas masyarakat di Taman Wisata Alam Tangkoko adalah untuk mencukupi kebutuhan keluarga mereka dan untuk melihat satwa yang ada serta keindahan alam.

Data tersebut menunjukan bahwa masih ada sebagian masyarakat di sekitar Taman Wisata Alam Tangkoko pernah melakukan penangkapan atau perburuan satwa liar khususnya untuk babi hutan. Hal ini dilakukan untuk memenuhi kebutuhan. Masyarakat yang melihat adanya perburuan terhadap satwa liar 28\%, sedangkan masyarakat (responden) yang tidak melihat dan tidak mengetahui adaya perbuaruan satwa liar yang dilindungi mencapai persentas $72 \%$.

Hasil ini menunjukan bahwa jika ada upaya perlindungan dari berbagai pihak baik Pemerintah terkait, akademisi, dan masyarakat maka upaya pelestarian satwa liar endemik yang dilindungi akan berjalan dengan baik.

\section{Respon masyarakat terhadap pengembangan ekowisata berbasis fauna endemik di Taman Wisata Alam Tangkoko}

Usaha pengembangan ekowisata sangat menguntugkan tidak hanya bagi pelaku bisnis, dan pemerintah tetapi bagi penduduk setempat dan lingkungannya. Dengan konsep ini maka harus meminimalkan dampak negatif dari mass tourism dari segi lingkungan, budaya, dan sosial. Ekowisata memiliki tujuan edukatif yang menyebarkan pesan konservasi dan pemahaman mengenai daerah yang dikunjungi.

Berdasarkan hasil penelitian bahwa Taman Wisata Alam Tangkoko memiliki berbagai fauna endemik dan flora khas, fauna endemik ini bisa dikembangan dan dipasarkan keseluruh dunia karena 
memiliki keunikan tersendiri namun dibutuhkan dukungan dan respon dari masyarakat setempat terhadap upaya pemerintah dalam mengembangkan fauna endemik dengan menjadikan daerah ekowisata. Dari hasil analisa menunjukan bahwa persentase respon masyarakat terhadap pengembangan ekowisata fauna endemik di Taman Wisata Alam Tangkoko sangat berbeda-beda. Tetapi pada prisipnya masyarakat kurang memahami apa maksud dengan adanya pengembangan ekowisata. Persentase masyarakat yang kurang setuju di temukan 53,3\% dan yang setuju 46,7\%, hal ini memungkinan berpengaruh karna mereka kurang mengerti mengenai ekowisata fauna dapat dilihat dengan persentase hanya $45,3 \%$ yang mengerti ekowisata fauna sedangkan masyarakat yang tidak mengerti tentang ekowisata fauna ditemukan ada $54,7 \%$.

Data tersebut menunjukan bahwa masyarakat kurang memahami apa maksud dan tujuan adanya pengembangan ekowisata fauna, karena ada beberapa alasan jika ekowisata dikembangkan maka akan merusak ekosistem yang asli dengan adanya pengembangan, karena status kawasan Cagar Alam bukan hutan wisata, adanya ancaman atau gangguan manusia (individu maupun pengembangannya) dan karena kurangnya sosialisasi dari pihak terkait atas program ini.
Pemerintah harus mempunyai inisiatif dan dapat secara mandiri mengembangkan potensi pariwisata termasuk ekowisata berbasis fauna endemik, karena pemerintah daerah mempunyai kewenangan untuk merencanakan, melaksanakan dan mengelola kegiatan ekowisata untuk kesejahteraan masyarakat dan secara tidak langsung dapat meninggkatkan PAD. Adanya kewenangan daerah yang sesuai dengan kebijakan dan peraturan daerah membuat pemerintah daerah perlu mengelolah potensi ekowisata secara mandiri termasuk pengembangan kelembagaan dalam mengembangkan ekowisata di tingkat daerah

\section{Peran Instansi Dalam Konservasi Sumber Daya Alam di Taman Wisata Alam Tangkoko}

Tangkoko Batuangus merupakan salah satu dari hutan yang berada di Sulawesi Utara, hutan ini memiliki keaneka ragaman hayati yang harus menjadi perhatian dari pemerintah setempat. Hasil wawancara dengan masyarakat yang ada di sekitar Taman Wisata Alam Tangkoko mengindikasikan hahwa hanya sedikit sekali peran yang telah ditunjukkan oleh pemerintah dalam hal ini instansi yang terkait.

Masarakat yang bermukim di sekitar Taman Wisata Alam Tangkoko 
yang mengetahui adanya petugas konservasi sumber daya alam (KSDA) ditemukan $100 \%$, dikarenakan masyarakat tiggal berdekatan dengan hutan dan mengetahui adnya petugas yang selalu bertugas di hutan, sedangkan yang tidak mengetahui bisa dilihat di atas persentasenya $0 \%$.

Dilihat pula persentase masyarakat yang mengetahui adanya penyuluhan ditemukan $77,3 \%$, sedangkan tidak ada penyuluhan 22,7\%. Gambaran ini menunjukan bahwa perlu ditingkatkan lagi kinerja dari petugas KSDA di Tangkoko Batuangus Bitung. Perlu ada kerja sama antara masyarakat dan pemerintah guna melindungi dan mengembangkan potensi daerah dalam hal ini satwa liar endemik yang ada supaya tetap tejaga dan terhindar dari kepunahan. Kurang lebih 14 spesies satwa endemik yang pernah dilihat oleh masyarakat di Taman Wisata Alam Tangkoko ini sebagai bentuk suguhan alami terhadap kekayaan fauna.

\section{Pendapatan Masyarakat}

\section{Mata pencaharian masyarakat}

Mata pencaharian merupakan suatu usaha untuk memenuhi kebutuhan hidup (ekonomi) dengan cara bekerja (Yeblo et $a l ., 2015)$. Mata pencaharian masyarakat berbeda satu sama lain, maupun corak budaya masyarakat disamping kemampuan (skill) yang dimiliki. Faktor-faktor tersebut sangat berpengaruh terhadap corak mata pencaharian suatu masyarakat. Misalnya masyarakat yang tinggal di daerah dataran tinggi umumnya bermata pencaharian sebagai petani. Hal ini disebabkan karena wilayah dataran tinggi cocok untuk pertanian yang ditunjang oleh pasokan air yang memadai serta suhu yang mendukung bagi pertumbuhan tanaman. Berbeda halnya dengan masyarakat yang tinggal di wilayah dataran rendah, umumnya jarang ditemui masyarakat yang bermata pencaharian sebagai petani karena tidak ditunjang oleh pasokan air serta suhu yang memadai. Berbeda lagi dengan masyarakat yang tinggal di daerah pantai, umunya mereka bermata pencaharian sebagai nelayan. Hasil penelitian yang diperoleh dari masyarakat (responden) menunjukan bahwa masih ada masyarakat yang berada disekitar Taman Wisata Alam Tangkoko sering melakukan aktivitas di hutan guna kebutuhan keluarga mereka. Untuk lebih jelas tentang mata pencaharian masyarakat yang ada di sekitar Taman Wisata Alam Tangkoko dapat dilihat pada Diagram 3 . 


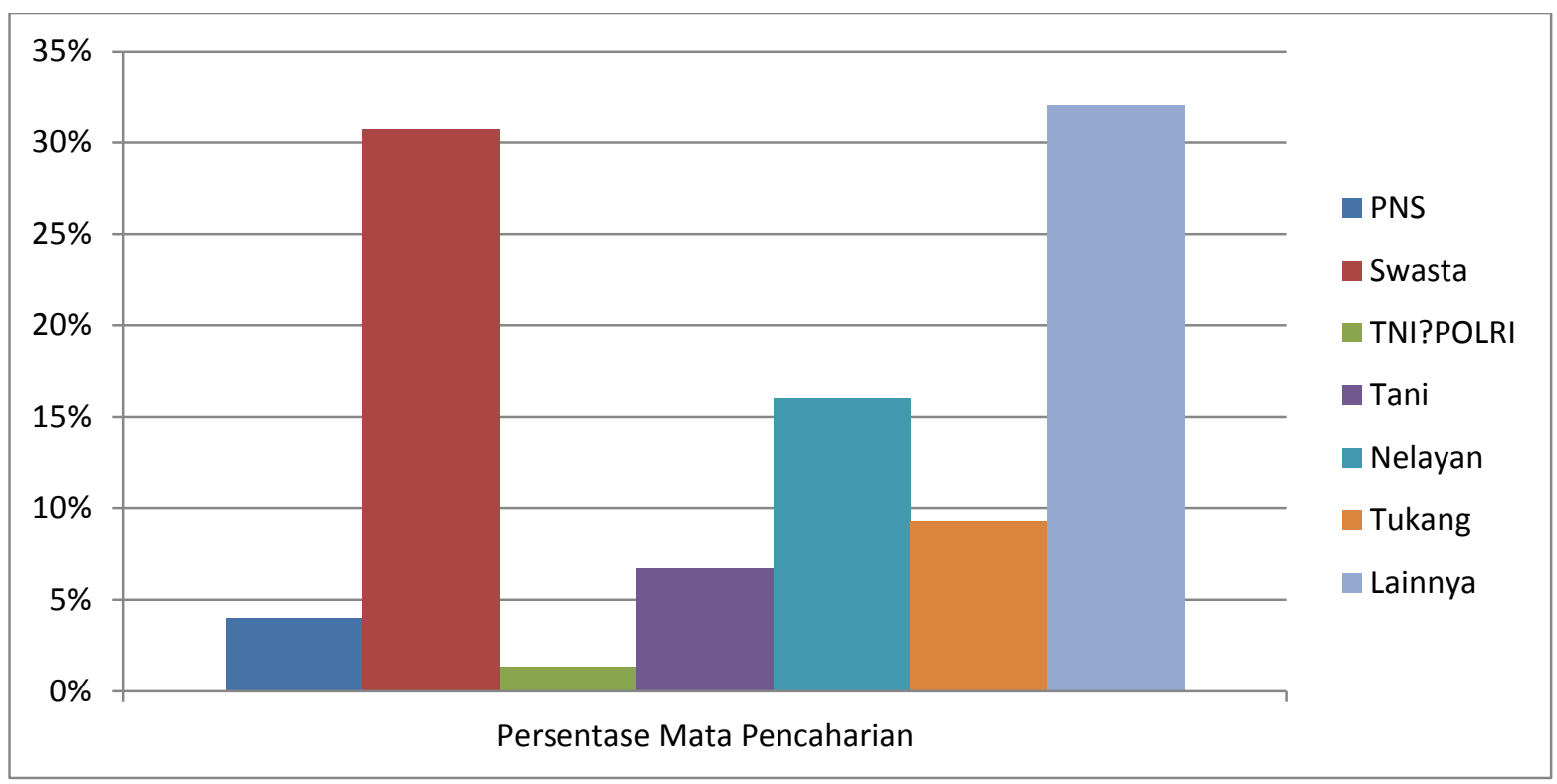

\section{Diagram 3. Persentase Mata Pencaharian Masyarakat (Responden) Disekitar TWA Tangkoko.}

Hasil persentase menunjukan mata pencaharian masyarakat umumnya bermata pencahariannya sebagai Swasta dibandingkan Pegawai Negeri Sipil (PNS) (6,7\%), Sedangkan Pegawai Swasta tertinggi $(33,3 \%)$. Masyarakat yang hanya berprofesi TNI/POLRI didapatnya $(0 \%)$. Berbeda dengan masyarakat yang mata pencahariannya sebagai petani adalah (4\%), sedangkan untuk masyarakat yang mata pencahariannya sebagai nelayan (20\%). Begiu pula dengan masyarakat yang mata pencahariannya sebagai tukang sama dengan persentase pegawai negeri sipil (PNS) yaitu $(6,7 \%)$.

Selain mata pencaharian diatas terdapat juga pekerjaan lain yang dimiliki masyarakat di sekitar Taman Wisata Alam Tangkoko dengan persentase $(29,3 \%)$ sebagai honorer, pensiunan, pendeta, sopir, ojek, pemandu wisata dan juga ibu rumah tangga. Masyarakat yang dulunya mata pencaharian sebagai nelayan dengan pendapatan berkisar antara 500.000600.000 perbulan, Namun setelah adanya pengembangan ekowisata masyarakat dapat membuka tempat penginapan atau sebagian ada yang menjadi pemandu, sehingga pendapatan mereka meninggkat dulunya hanya berkisar Rp.500.000 Rp.600.000 perbulan sekarang berkisar 1.000.000-6.000.000 perbulan. Apalagi pada tanggal 01 September 2016 telah di tetapkan bahwa jasa pemandu sebesar Rp. 200.000 perorang (dalam waktu 4 jam perjalanan) baik dalam hari kerja maupun hari libur, dapat dilihat pada Tabel 1. 
Tabel 1. Pendapatan rata-rata pengusaha penginapan di Taman Wisata Alam Tangkoko

\begin{tabular}{clcc}
\hline No & \multicolumn{1}{c}{ Penginapan } & Rata-rata perbulan & Pertahun \\
\hline 1 & Tangkoko Dove Villa's and Resto & 4.000 .000 & 48000000 \\
2 & Tangkoko Hill Cottage and Resto & 3.000 .000 & 36000000 \\
3 & Tangkoko Lodge & 5.000 .000 & 60000000 \\
4 & Mama Roos Home Stay & 2.000 .000 & 24000000 \\
5 & Tangkoko Ranger Home Stay & 6.000 .000 & 72000000 \\
6 & Tarsius Home Stay & 3.000 .000 & 36000000 \\
7 & Tangkoko Angrek Home Stay & 2.000 .000 & 24000000 \\
\hline & $\quad$ TOTAL & 25.000 .000 & 300.000 .000 \\
\hline
\end{tabular}

Pada Tabel 1, dapat dilihat dari tabel bahwa jumlah perbulan dari berbagai penginapan berbeda-beda dan yang paling banyak pendapatannya yaitu penginapan Tangkoko Ranger Home Stay, dan secara keseluruhan penginapan mendapatkan pendapatan tambahan sebesar Rp.300.000.000 pertahun. Berdasarkan jenis pekerjaan yang diperoleh masyarakat yang ada disekitar Taman Wisata Alam Tangkoko pemerintah setempat dapat lebih memperhatikan agar supaya usaha pengembangan dan pelestarian flora dan fauna yang diupayakan oleh pemerintah bisa berjalan dengan baik. Pengembangan pariwisata di suatu daerah akan berdampak pada perubahan struktur ekonomi masyarakat khususnya mata pencaharian masyarakat yang ditimbulkan dari adanya peluangusaha sektor tersebut dan ikutannya (Suardana dan Dewi, 2015).

\section{Masyarakat (Responden) Yang Mempunyai Manfaat dan Penghasilan Tambahan Serta Ikut Berpartisipasi Dalam Program Ekowisata.}

Kesempatan kerja yang berasal dari sektor ekowisata bisa menjadi penghasilan tambahan bagi keluarga (Hijriati dan Mardiana, 2014). Masyarakat yang mempunyai manfaat sebagai penghasil tambahan adalah 53,3\% sedangkan yang tidak mempunyai manfaat tambahan 46,7\%. Hal ini menunjukan bahwa tidak semua masyarakat memiliki manfaat dengan adanya program ekowisata. Hal ini dilihat dari persentase masyarakat yang mepunyai penghasilan tambahan dengan adanya program ekowisata ditemukan $66,7 \%$, sedangkan masyarakat yang tidak mendapat penghasilan tambahan persentasenya 33,3\%. Data ini menunjukan banyaknya masyarakat yang memiliki pendapatan tambahan dari program ekowisata, sedangkan yang tidak 
mendapatkan pendapatan tambahan dikarenakan masyarakat tidak terkait atau tidak bekerja dalam bidang ekowisata.

Persentase masyarakat yang ikut berpartisipasi dalam program pengembangan ekowisata di Taman Wisata Alam Tangkoko sangat banyak yaitu 80\%, sedangkan yang tidak ikut berpartisipasi ditemukan persentase 20\%, hal ini menunjukan bahwa jika masyarakat berpartisipasi dengan program ekowisata maka pengembangan ekowisata di Taman Wisata Alam Tangkoko akan lebih maju lagi. Adapula tanggapan masyrakat mengenai program ekowisata dikatakan bahwa ekowisata harus lebih dikembangkan lagi, karena sangat baik bagi pengusaha losmen serta petugas dan pemandu, karena akan menambah pendapatan keluarga.

\section{Pendapatan daerah Kota Bitung}

Rantetadung (2012), menyatakan bahwa pengaruh kunjungan wisatawan sangat berarti untuk pengembangan industri pariwisata dan pendapatan asli daerah sehingga wisatawan domestik maupun wisatawan mancanegara tertarik untuk berkunjung. Sebagai sumber penerimaan pendapatan, pariwisata tidak terlepas dari pengaruh jumlah kunjungan wisatawan. Majunya sektor pariwisata disuatu daerah sangat bergantung kepada jumlah wisatawan yang berkunjung (Purwanti dan Dewi, 2014). Kedatangan wisatawan tersebut akan mendatangkan penerimaan bagi daerah yang dikunjunginya. Dapat dilihat pada Tabel 2 di bawah yang menunjukkan jumlah kunjungan wisatawan di kota Bitung. Bagi wisatawan mancanegara yang datang dari luar negeri, kedatangan mereka akan mendatangkan devisa dalam negara. Semakin banyaknya wisatawan yang berkunjung maka akan memberi dampak yang positif bagi daerah tujuan wisata terutama sebagai sumber pendapatan daerah. Jadi dapat dikatakan bahwa salah satu sumber PAD yaitu harga tanda masuk (HTM) yaitu tiket yang ada di Taman Wisata Alam Tangkoko. Hasil penelitian menunjukan bahwa jumlah turis mancanegara dan domestik yang berkunjung di tahun 2016 sejumlah 2.498 orang. Dapat dilihat pada perhitungan PAD berdasarkan hitungan HTM terdapat pada Tabel 3. Bisa dilihat Pada Tabel 3 diatas, jumlah kunjungan pertahun berbeda-beda namun pada tahun 2016 terdapat peningkatan kunjungan. Wisatwan yang datang bersumber dari resort resort di Pulau Lembeh, Pos BKSDA Batu Putih, Kantor Imigrasi Kelas II Bitung, Festival Pesona Selat Lembeh 2016, Kapal Pesiar dan Objek Wisata. Tabel 3 menunjukkan bahwa jumlah pengunjung berpengaruh terhadap pendapatan asli daerah (PAD) 
Tabel 2. Jumlah Kunjungan Wisatawan Kota Bitung Tahun 2012 - 2016

\begin{tabular}{llll}
\hline Tahun & $\begin{array}{l}\text { Wisatawan } \\
\text { Mancanegara }\end{array}$ & $\begin{array}{l}\text { Wisatawan } \\
\text { Domestik }\end{array}$ & Total \\
\hline 2012 & 6.488 & 6.988 & 13.476 \\
2013 & 2.530 & 5.650 & 8.180 \\
2014 & 1.421 & 8.300 & 9.721 \\
2015 & 11.753 & 7.114 & 18.867 \\
2016 & 24.334 & 26.764 & 51.098 \\
\hline
\end{tabular}

Tabel 3. Perhitungan PAD Berdasarkan HTM di Taman Wisata Alam Tangkoko Tahun 2016.

\begin{tabular}{ccccccr}
\hline \multirow{2}{*}{ Bulan } & \multicolumn{2}{c}{ Pengunjung } & \multicolumn{2}{c}{ HTM } & \multicolumn{2}{c}{ Total } \\
\cline { 2 - 6 } & Mancanegara & Domestik & Mancanegara & Domestik & Mancanegara & Domestik \\
\hline Januari & 165 & 5 & 100.000 & 5.000 & 16500000 & 25000 \\
Februari & 187 & 9 & 100.000 & 5.000 & 18700000 & 45000 \\
Maret & 202 & 23 & 100.000 & 5.000 & 20200000 & 115000 \\
April & 221 & 33 & 100.000 & 5.000 & 22100000 & 165000 \\
Mei & 194 & 32 & 100.000 & 5.000 & 19400000 & 160000 \\
Juni & 170 & 20 & 100.000 & 5.000 & 17000000 & 100000 \\
Juli & 303 & 42 & 100.000 & 5.000 & 30300000 & 210000 \\
Agustus & 310 & 8 & 100.000 & 5.000 & 31000000 & 40000 \\
September & 184 & 8 & 100.000 & 5.000 & 18400000 & 40000 \\
Oktober & 120 & 10 & 100.000 & 5.000 & 12000000 & 50000 \\
November & 128 & 9 & 100.000 & 5.000 & 12800000 & 45000 \\
Desember & 110 & 5 & 100.000 & 5.000 & 11000000 & 25000 \\
\hline Total & 2.294 & 204 & & & 229400000 & 1020000 \\
\hline
\end{tabular}

dapat di lihat pula pada Tabel 4, target pajak daerah Tahun 2016 yang bersangkutan dengan program ekowisata secara keseluruhan. Hasil wawancara dengan PEMKOT menunjukan terjadi kenaikan pendapatan daerah sejak digalakannya program ekowisata di Tangkoko, dan setiap tahun selalu mencapai target. Pemerintah menyadari bahwa sektor pariwisata bukanlah merupakan sektor penyumbang terbesar dalam pendapatan daerah, tetapi berpotensi dalam meningkatkan PAD. 
Tabel 4. Target Pajak Daerah Tahun 2016 Yang Bersangkutan Dengan Program Ekowisata di Kota Bitung.

\begin{tabular}{ccc}
\hline No & Jenis Pajak & Target Tahun \\
& & 2016 \\
\hline 1 & Hotel & 1.627 .000 .000 \\
2 & Restoran & 2.150 .000 .000 \\
3 & Hiburan & 300.000 .000 \\
\hline Total & & 4.077 .000 .000 \\
\hline
\end{tabular}

Di Indonesia mempunyai potensi alam dan seni budaya yang besar yang dapat dimanfaatkan oleh daerah untuk meningkatkan PAD (Wahyuni, 2016).

\section{Dampak Ekowisata}

Kawasan Cagar alam Tangkoko telah lama dijadikan salah satu tujuan wisata di Sulut. Secara teoritis ekowisata dilarang di Cagar alam Tangkoko karena status kawasan tersebut, tetapi kegiatan ekowisata tetap saja berjalan di dalam kawasan. Kawasan Cagar Alam Tangkoko sering dipromosikan oleh biro perjalanan dan dinas pariwisata sebagai salah satu tujuan wisata di Sulut, walaupun belum dimasukkan dalam rencana pengembangan pariwisata daerah. Kegiatan ekowisata di Cagar Alam Tangkoko telah lama dianggap sebagai salah satu ancaman bagi kelestarian kawasan, karena pengelolaannya yang tidak baik. Hal tersebut juga memungkinkan keterlibatan pemerintah daerah dan para pengelola jasa wisata alam untuk ikut mengelola kawasan. Sampai saat ini wacana perubahan status masih menjadi topik menarik di antara pelaku ekowisata. Perkembangan pariwisata berdampak terhadap kondisi sosial ekonomi masyarakat, salah satu diantaranya adalah dampak pariwisata terhadap pendapatan pemerintah.

\section{Dampak Positif}

Dari data responden yang di dapat ada $96 \%$ dari 25 orang wisatawan yang tidak pernah memberi makan satwa yang ada di kawasan tersebut. hal ini menunjukaan bahwa wisatawan sangat mengerti bahwa tidak diperbolehkan untuk memberi makan satwa yang ada, dikarnakan adanya larangan dari pemerintah atau petugas yang ada. Adapula dampak positif dengan adanya pengembangan ekowisata di TWA Tangkoko yaitu dapat dilihat dari segi ekonomi dimana masyarakat sekitar mendapat pendapatan tambahan mereka 
yang dulunya hanya sebagai nelayan kini mendapat pekerjaan tambahan menjadi guide, pemerintah juga mendapat pendapatan dari pajak bangunan karna masyarakat sekitar membangun penginapan untuk para wisatawan, dapat dilihat juga dari segi sosial, tempat (Taman Wisata Alam Tangkoko) dan satwa tersebut akan lebih di kenal di mata dunia, dan dilihat dari segi ilmu, mahasiswa atau ilmuan dapat melakukan penelitian, siswasiswa dapat belajar mengenal hutan dan kelestariannya,

\section{Dampak negatif}

Dari data persentase responden di temukan 4\% wisatawan (responden) yang masih memberi makan kepada satwa yang ada dalam kawasan Taman Wisata Alam Tangkoko, karena wisatawan (responden) belum tau tentang adanya larangan tidak boleh memberi makan satwa yang ada. Menurut Alikodra (2002), bahwa akibat kurangnya kasadaran dari masyarakat mengakibatkan kerusakan ekosistem dalam jangka waktu yang tidak terlalu lama dapat mengancam keberadaan hidup flora dan fauna karena dengan kondisi demikian. Jika hal ini terus terjadi maka akan berdampak negatif terhadap satwa tersebut dikarnakan satwa yang ada adalah satwa liar, dan satwa liar harus mencari makanan dengan sendirinya, dan jika memberi makan kepada satwa dapat merubah tingkalaku dari satwa tersebut, mereka juga tidak mau mencari makanan sendiri di hutan dan hanya menunggu manusia untuk memberi makan, maka mereka tidak akan bertahan dan mati dengan demikian rantai makanan akan rusak, dan akan berdampak negatif terhadap masyarakat yang ada disekitar kawasan Taman Wisata Alam Tangkoko.

Dampak negatif dari wisatawan atau pengunjung, wisatawan cenderung mebuang sampah sembarangan dilingkungan tempat hidup satwa, satwa tersebut akan makan sampah dari wisatawan, dan lingkungan hutan akan menjadi kotor.

\section{KESIMPULAN}

Dari data dan hasil pembahasan maka dapat disimpulkan bahwa program Ekowisata berbasis fauna endemik baik untuk dikembangkan karena dapat memberi dampak positif terhadap usaha konservasi, dan juga dapat meningkatkan pendapatan masyarakat serta pendapatan daerah.

\section{DAFTAR PUSTAKA}

Alikodra, S. M. 2002. Pengelolaan Satwa Liar, Jilid I. IPB Bogor.

Hakim, S. S. 2010. Kondisi Umum Cagar Alam Gunung Tangkoko dan Dua saudara. 
.Hijriati, E dan R. Mardiana. 2014. Pengaruh ekowisata berbasis masyarakat terhadap perubahan kondisi Ekologi, Sosial dan Ekonomi Di Kampung Batusuhunan, Sukabumi. Jurnal Sosiologi Pedesaan. Vol. 2 (3): 146159.

Purwanti, N. D dan R.M. Dewi. 2014. Pengaruh kunjungan wisatawan terhadap pendapatan asli daerah Kabupaten Mojokerto Tahun 20062013. Jurnal Ilmiah Universitas Negeri Surabaya

Rantetadung, M. 2012. Analisis pengaruh dukungan pemerintah dan kunjungan wisatawan terhadap pendapatan asli daerah di Kabupaten Nabire. Jurnal Agroforensi. Vol 7 (1): 25-32
Suardana I dan Dewi N . 2015. Dampak pariwisata terhadap mata pencaharian masyarakat pesisir Karangasem; Pendekatan Pro Poor Tourism. Jurnal Piramida Vol.XI (2) :76-87.

Tarmudji dan J. MacKinnon. 1980. Cagar Alam Tangkoko-Dua Saudara Rencana Pengelolaan 1981-1986. Jakarta : World Wildlife Fund.

Wahyuni, S. 2016. Kebijakan Pemerintah Daerah Di Bidang Pariwisata Dalam Meningkatkan PAD Di Kabupaten Muna Provinsi Sulawesi Tenggara.

Yeblo, M., H.J. Kiroh, M.J. Nangoy, V.R.W. Rawung. 2015. Beberapa faktor pendukung pengembangan ekowisata berbasis fauna endemik di hutan sawinggrai kecamatan miosmansar kabupaten kepulauan raja ampat propinsi papuan barat. Jurnal Zootek 35 (2): 210-224 . 